Rubin, M. \& Bird, H. R. (1943). Poult. Sci. 22, 53.

Smythe, C. V. \& King, C. G. (1942). F. biol. Chem. r42, 529.

Sure, B., Theis, R. M. \& Harrelson, R. T. (1939). F. biol. Chem. 129, 245.

Sutton, T. S., Kaeser, H. E. \& Hansard, S. L. (1942). F. biol. Chem. 144, 183.

Wolbach, S. B. \& Howe, P. R. (1933). Amer. F. Path. 9, 275.

Yudkin, S. (1941). Biochem. F. 35, 551 .

\title{
Comparison of Eye changes in Riboflavin Deficiency and in Tryptophan Deficiency in the Rat
}

\author{
By ANTOINETTE PIRIE, Nuffield Laboratory of Ophthalmology, Oxford
}

\section{(Received 19 September 1947)}

Deficiency of many different substances causes corneal vascularization in rats. It has been reported in vitamin A deficiency by Stephenson \& Clark (r920), in riboflavin deficiency by Bessey \& Wolbach (1939), in tryptophan deficiency and lysine deficiency by Totter \& Day (1942), in methionine and in protein deficiencies by Sydenstricker, Hall, Hock \& Pund (1946), in sodium deficiency by Follis, Day \& McCollum (194I), in zinc deficiency by Follis, Orent-Keiles \& McCollum (r942), in thallium poisoning by Donski (1932) and, on certain diets, in tyrosine and phenylalanine excess by Niven, Washburn \& Sperling (1946). The problem which has confronted everyone working in this field has been to account for this common sign arising from the lack in the food of so many entirely different substances or from the excess of others. Each deficiency may affect the corneal cells directly or indirectly through changes in the blood supply, and in the composition of the aqueous humour or lacrimal secretions. There may be many different stimuli for the ingrowth of corneal vessels, each deficiency providing one such stimulus, or, on the other hand, there may be a common factor among the changes caused by the lack of each separate substance and this may be the single stimulus for corneal vascularization. When an animal lacks a substance essential to life, many of its catabolic and synthetic systems are put out of gear so that in some cases induced deficiencies of other essential substances may occur. For example, Moore (1940) found that in rats lack of vitamin $E$ impaired the storage of vitamin $A$. Boyer, Phillips, Pounden, Jensen, Rupel \& Nesbit (1942) found that vitamin A-deficient rats had a lowered tissue vitamin C, and Pirie \& Wood (1946) found that vitamin Adeficient rabbits had lowered vitamin $C$ in their aqueous humour. Albanese, Holt, Kajdi \& Frankston (1943) found that tryptophan deficiency caused a reduction in haemoglobin and plasma protein, and Rosen, Huff \& Perlzweig (1946) found that nicotinic acid synthesis in the rat was depressed in tryptophan deficiency. Thus, each deficiency has repercussions on other, at first sight unrelated, chemical processes of the animal and may in this way lead to an unspecific common tissue reaction, e.g. corneal vascularization, although the primary function of the substance that is lacking is specific and unique. 
During a study of the effect of riboflavin and tryptophan deficiency on the metabolism of the different parts of the eye of the rat, I noticed certain similarities between the signs of the two deficiencies which do not seem to have been reported previously. The two most noticeable similarities were that in both the eyeball grew at a normal rate although the growth of the animal as a whole was much retarded, and that the Harderian glands of the deficient animals were abnormally small and showed similar histological changes. Some evidence was obtained that synthesis or storage of ascorbic acid was upset in tryptophan deficiency. A lowered tissue concentration of ascorbic acid in riboflavin deficiency has already been reported by other workers. A brief account of these observations is given in order to show the complexity of the changes in such deficient animals.

\section{Riboflavin deficiency}

\section{METHODS}

The rats were partly albinos and partly black and whites from the laboratories of the Pharmaceutical Society of Great Britain. All were put on the deficient diet at weaning. This diet was the standard one in use at the Pharmaceutical Society for testing the riboflavin content of food materials and had the following composition: dextrinized rice starch 79 parts, casein (Glaxo ashless extracted A/E) I 5 parts, salts (Steenbock mixture 40) 4 parts. In addition, each rat received twice weekly five drops of cod-liver

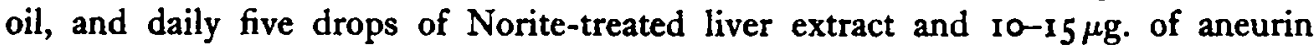
hydrochloride. Water was freely available. Control rats were given a stock diet of rat cubes (Joseph Thorley Ltd.) consisting of wheat 19.3, Sussex-ground oats 19.1, barley 7.5 , maize meal 9.4 , dried milk 14.0 , fish meal 5.0 , dried yeast 1.2 , salt 0.53 , cod-liver oil 0.53 , molasses 1.94 , meat-and-bone meal 9.4 , and weatings $12.1 \%$.

\section{Tryptophan deficiency}

The rats were black and whites from the Medical Research Council's stock. All were put on the following diet at weaning: dextrinized rice starch 72 parts, acidhydrolysed casein (Glaxo) I5 parts (dry wt.), salts (Steenbock mixture 40) 4 parts, cod-liver oil 5 parts, dried brewer's yeast 4 parts, cystine 0.3 part. The diet was mixed with a warm $2.5 \%$ solution of agar and allowed to set in shallow trays. After cooling it was cut in cubes and fed ad lib. Water was freely available. Four rats were fed a mixture of the above diet with $0.2 \%$ tryptophan added, and part of the way through the experiment four were fed rat cubes in quantities corresponding to the amount of food eaten by the tryptophan-deficient rats, whose daily food intake was measured over a short period.

\section{Examination of rats}

The rats were weighed twice weekly and their eyes examined once or twice each week with slit lamp and ophthalmoscope. The deficient animals were killed for examination when signs of deficiency were well established, and the control ones when convenient for the experiment. 


\section{Estimation of ascorbic acid}

The weighed tissues were ground with a small amount of sand and a known volume of $5 \%(\mathrm{w} / \mathrm{v})$ metaphosphoric acid, and the suspension centrifuged. Ascorbic acid was estimated in the supernatant fluid by titration with 2:6-dichlorophenolindophenol (Birch, Harris \& Ray, 1933).

\section{RESULTS}

The course of riboflavin deficiency in the rat has been described in detail by Bessey $\&$ Wolbach (1939). In the present study the rats showed the usual signs of lack of growth, corneal epithelial change, bilateral circumferential corneal vascularization and cellular infiltration into the corneal stroma.

Tryptophan deficiency in the rat has been described by Totter \& Day (1942) and the eye changes have been especially noted by Buschke (r943). The rats in the present study showed the same corneal changes as those noted by the earlier observers. The epithelial 'sanded' appearance and the type of corneal vascularization were indistinguishable from those observed in the riboflavin-deficient rats. The animals on the deficient diet with tryptophan grew satisfactorily and showed no changes in their eyes, while those fed the stock diet in amounts restricted to the quantity of food eaten by the deficient rats grew very slowly but showed no pathological changes.

\section{Effect of deficiency of riboflavin and of tryptophan on eye growth}

The growth of the whole animal was much retarded in both deficiencies, but the growth of the eyeball proceeded at a normal rate with the result that the deficient animals had relatively large eyes in undersized bodies. This was the more surprising, as one of the first signs of both riboflavin and tryptophan deficiency is that the eye recedes into the socket and the lids almost close over it. This appeared to be due to the small size of the Harderian gland in the deficient animals. This gland is the main intraorbital gland in the rat and normally weighs nearly as much as the eyeball itself. It is horseshoe-shaped and lies behind the eye pressing it forward in the socket. In the deficient animals the Harderian glands were about half the normal size and therefore allowed the eye to sink back into the socket.

Figs. I- 6 show the weight/age relationships of the eyes and Harderian glands of normal, riboflavin-deficient and tryptophan-deficient rats, together with the weight charts of the rats themselves. They show that both deficiencies have a depressing effect on the total growth and on the growth of the Harderian gland, but have little effect on growth of the eyeball.

Sections made of the Harderian glands from both riboflavin- and tryptophandeficient rats showed the same type of pathological change (Plate 1 ). There was no increase in fibrous tissue, the fluorescence of the whole gland was unchanged and, in parts of the gland, the cells seemed to be normal; but in parts there were dense infiltrations of darkly staining lymphocytes which replaced the glandular tissue.

In order to see whether lack of Harderian secretion caused pathological changes in the cornea, the Harderian glands were removed from the right sockets of four rats, 


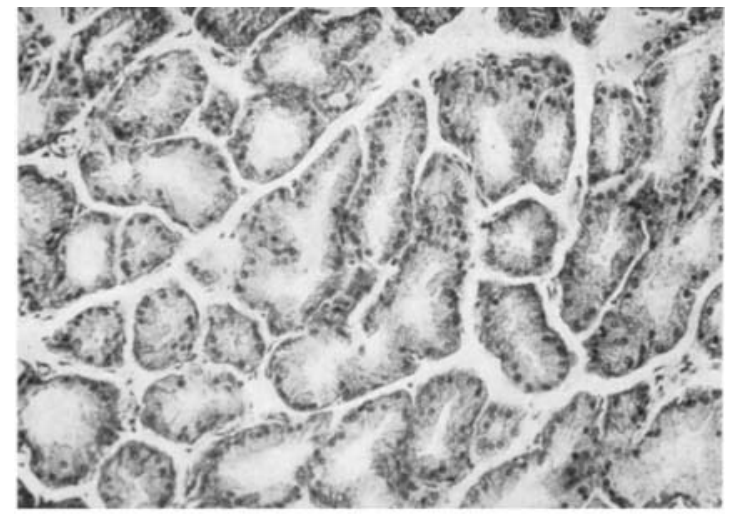

(1)

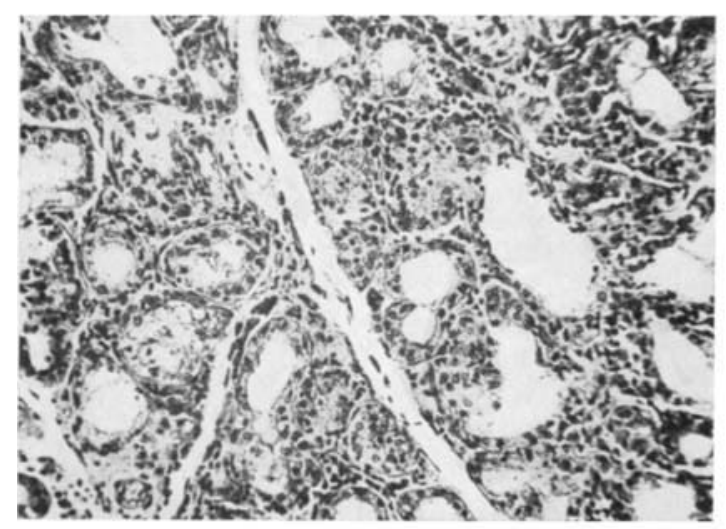

(2)

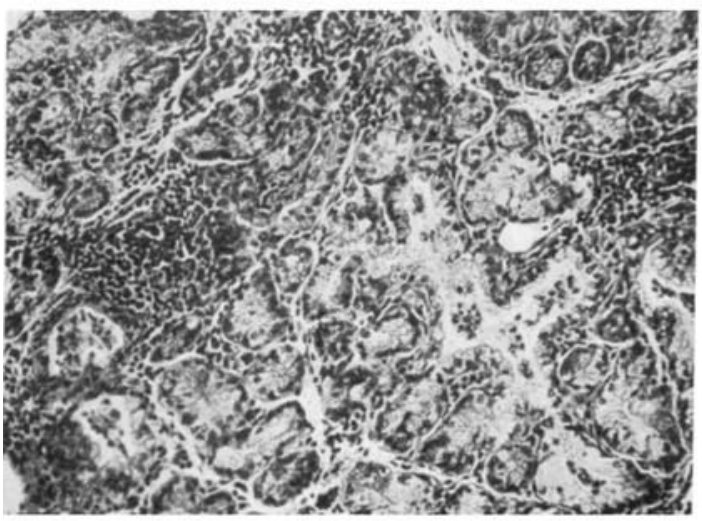

(3)

Photomicrographs of I Iarderian glands of (1) normal, (2) tryptophan-deficient and (3) riboflavin-deficient rats. $\times 200$.

A. PIRIE. Eye Changes in Riboflavin and thyptomian DEFICIENCY 
using the suction method described by Figge \& Salomon (1942), and the eyes were watched for 2 months afterwards with the slit lamp. Examination of the cornea was difficult owing to the retraction of the eye into the socket, but the cornea remained

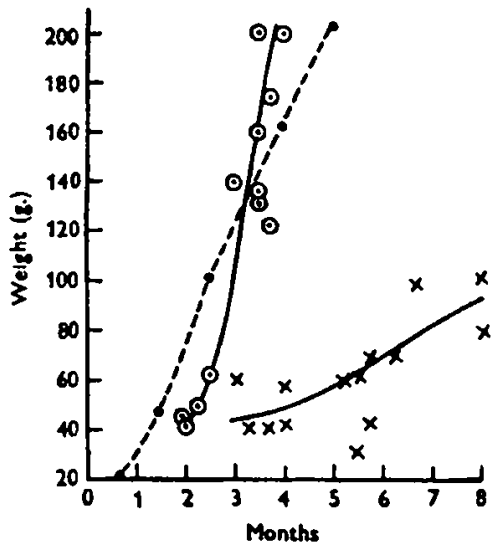

Fig. 1

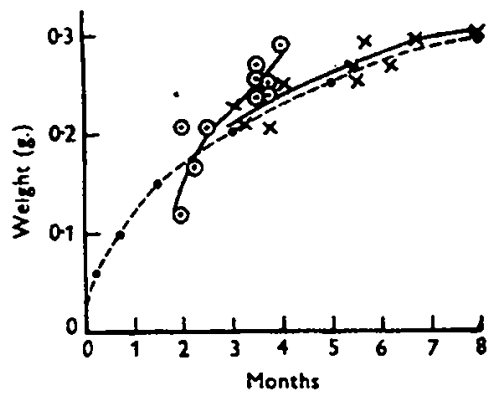

Fig. 3

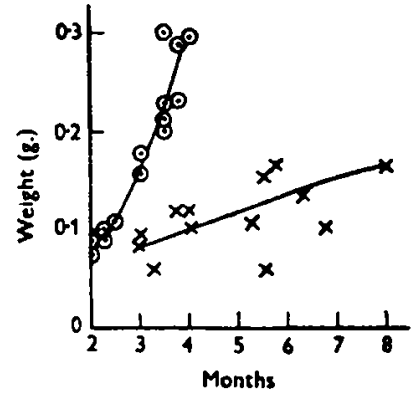

Fig. 2

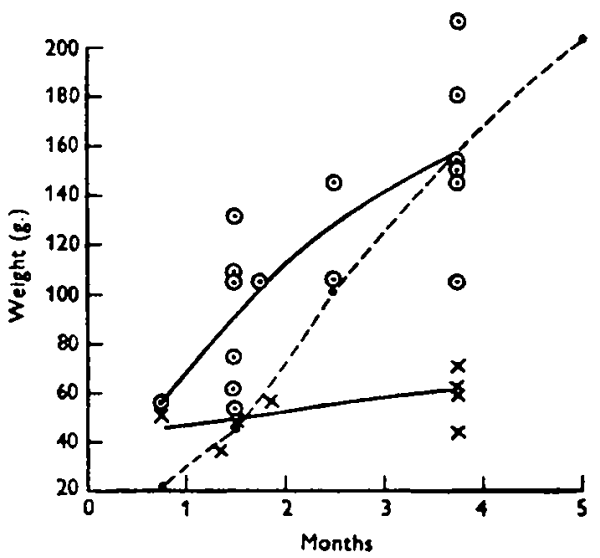

Fig. 4

Fig. 1. Weight at death of control $\odot-\odot$ and riboflavin-deficient $\times \longrightarrow \times$ rats. Data from Donaldson (1924) for normal rats -...- also given for comparison.

Fig. 2. Weight of Harderian glands at death of control $\odot \longrightarrow \odot$ and riboflavin-deficient $\times \longrightarrow \times$ rats.

Fig. 3. Weight of eyes at death of control $\odot \longrightarrow \odot$ and riboflavin-deficient $\times \longrightarrow \times$ rats. Data from Jackson (1913) for weight of normal eye - . . - of rat also given for comparison.

Fig. 4. Weight at death of control $\odot-\odot$ and tryptophan-deficient $x-\times$ rats. Data from Donaldson (1924) for weight of normal rat - . . . also given for comparison.

clear and bright and showed no sign of drying or of vascularization. The rats were killed after 2 months, and dissection showed that no Harderian tissue was left. The loss of Harderian secretion therefore is not sufficient by itself to cause corneal vascularization. 


\section{Effect of deficiency of tryptophan on ascorbic acid metabolism}

Several workers have suggested that the synthesis of ascorbic acid is upset in riboflavin deficiency. Ray, György \& Harris (1935) found that the lenses of rats deficient in the vitamin B complex contained less ascorbic acid than the normal lens, while Sure, Theis \& Harrison (1939) found that rats deficient in riboflavin or aneurin had low tissue concentrations of the factor. With this evidence in mind it seemed worth while to investigate the effect of tryptophan deficiency on the ascorbic acid content of lens and Harderian gland.

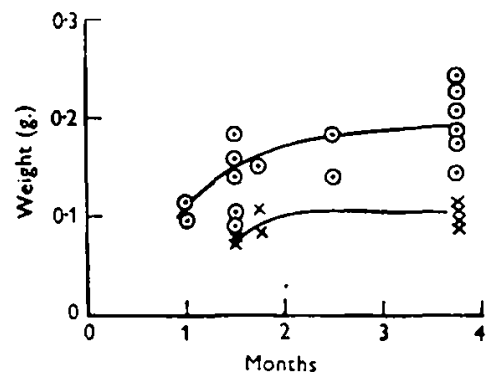

Fig. 5

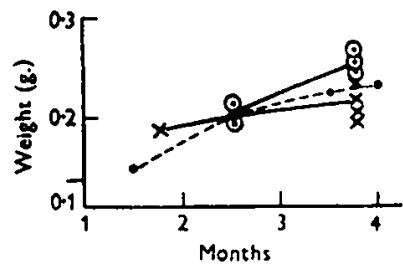

Fig. 6

Fig. 5. Weight of Harderian glands at death of control $\odot-\odot$ and tryptophan-deficient $\times-x$ rats.

Fig. 6. Weight of eyes at death of control $\odot-\odot$ and of tryptophan-deficient $\times-\times$ rats. Data

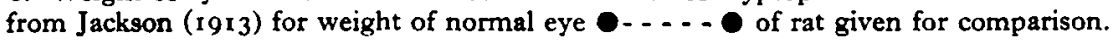

The Harderian glands of tryptophan-deficient rats contained only about half the normal concentration of ascorbic acid, but the concentration in the lens was the same as that for the control rats. The concentration found in the lenses of the controls was lower than that reported by Bellows (1944), perhaps owing to a difference in diet or strain of animal. Some rats in each group were given $\mathrm{I} g$. of fresh parsley daily to provide about $2.5 \mathrm{mg}$. ascorbic acid in order to see whether this outside source would raise the concentration in the Harderian glands. The rats ate the parsley with frantic eagerness but it seemed to have no effect on the ascorbic acid of the gland or on the signs of tryptophan deficiency. Table I shows that all groups except the tryptophandeficient animals had an average of $80 \mathrm{mg} . / 100 \mathrm{~g}$. gland, but that the tryptophandeficient rats had an average of $46 \mathrm{mg} / \mathrm{roo}$ g. gland.

\section{DISCUSSION}

The specific effect of riboflavin deficiency is to reduce the concentration of flavoprotein enzymes and thus to reduce the oxidizing capacity of the tissues. Lee \& Hart (1944) found that the oxygen uptake of the cornea of riboflavin-deficient rats was less than that of normal animals. In tryptophan deficiency one specific effect is inability to synthesize those proteins that contain tryptophan in their molecules. This is reflected in almost complete and immediate stoppage of growth and must lead to widespread changes in metabolism. Totter \& Day (1942) found that addition of riboflavin to a 
tryptophan-deficient diet had no effect on the corneal vascularization, showing that this sign of tryptophan deficiency is not due to an induced deficiency of riboflavin.

Retardation of growth is a non-specific effect of nearly all deficiencies, and it seems characteristic of the eyeball that it is less affected than other tissues of the body. McMeekan (1940a, b, c) found that the weight of the eyeball in pigs fed on various diets ran parallel with the age of the pig rather than with its weight or state of nutrition, and Donaldson (1924) found the same thing for rats under unfavourable nutritional

Table 1. Ascorbic acid content of Harderian gland and lens of normal, restricted and tryptophan-deficient rats

\begin{tabular}{|c|c|c|c|c|c|c|c|c|c|c|}
\hline \multirow{2}{*}{$\begin{array}{l}\text { Diet } \\
\text { Rat cubes }\end{array}$} & \multirow[b]{2}{*}{$\begin{array}{l}\text { Organ } \\
\text { Harderian } \\
\text { gland } \\
\text { Lens }\end{array}$} & \multicolumn{8}{|c|}{$\begin{array}{c}\text { Individual values } \\
\text { (mg./100 g.) }\end{array}$} & \multirow{2}{*}{$\begin{array}{l}\text { Mean value } \\
\text { (mg./100 g.) } \\
\quad 79\end{array}$} \\
\hline & & & $\begin{array}{l}73 \\
9 \cdot 8\end{array}$ & $\begin{array}{l}60 \\
8 \cdot 5\end{array}$ & $\begin{array}{l}103 \\
8 \cdot 6\end{array}$ & $\begin{array}{l}81 \\
-\end{array}$ & $\begin{array}{l}73 \\
8 \cdot 8\end{array}$ & $\begin{array}{l}84 \\
9 \cdot 0\end{array}$ & & \\
\hline $\begin{array}{l}\text { Rat cubes (restricted } \\
\text { to amount of food } \\
\text { eaten by deficient } \\
\text { rats) }\end{array}$ & $\begin{array}{l}\text { Harderian } \\
\text { gland } \\
\text { Lens }\end{array}$ & & 100 & $\begin{array}{l}88 \\
-\end{array}$ & $\begin{array}{l}74 \\
-\end{array}$ & $\begin{array}{r}84 \\
-\end{array}$ & & & & $\begin{array}{l}85 \\
-\end{array}$ \\
\hline $\begin{array}{l}\text { Diet deficient in } \\
\text { tryptophan }+0.2 \% \\
\text { DL-tryptophan }\end{array}$ & $\begin{array}{l}\text { Harderian } \\
\text { gland } \\
\text { Lens }\end{array}$ & & $\begin{array}{l}66 \\
7 \cdot 6\end{array}$ & 77 & 86 & $\begin{array}{l}91 \\
8 \cdot 5\end{array}$ & & & & $\begin{array}{l}80 \\
7 \cdot 8\end{array}$ \\
\hline $\begin{array}{l}\text { Diet deficient in } \\
\text { tryptophan }\end{array}$ & $\begin{array}{l}\text { Harderian } \\
\text { gland } \\
\text { Lens }\end{array}$ & $\begin{array}{l}51 \\
10.4\end{array}$ & $\begin{array}{l}55 \\
7 \cdot 4\end{array}$ & $\begin{array}{l}37 \\
7 \cdot 9\end{array}$ & $\begin{array}{l}34 \\
8 \cdot 4\end{array}$ & $\begin{array}{l}65 \\
4.5\end{array}$ & $\begin{array}{l}61 \\
10.9\end{array}$ & 20 & $\begin{array}{l}45 \\
-\end{array}$ & $\begin{array}{l}4^{6} \\
8 \cdot 2\end{array}$ \\
\hline
\end{tabular}

circumstances. Tansley (1931) found that the retinas from vitamin A-deficient rats weighed as much as those from normal rats, and this may be taken as evidence that in these vitamin A-deficient animals the eye as a whole was as large as a normal eye.

On the other hand, there is some evidence that the Harderian gland of deficient animals shares in the general retardation of growth. Collins (1930) found atrophy of the Harderian gland in vitamin A-deficient rats, Bessey \& Wolbach (1939) found that sections of the glands from riboflavin-deficient rats showed none of the characteristic yellow secretion normally present in the glandular tissue, and Salmon \& Engel (1940) observed mild sloughing and some haemorrhages into the lumen of the gland in deficiency of pantothenic acid.

The changes in relative growth rate of the eye and its main gland reported here in riboflavin- and in tryptophan-deficient rats may also occur in other deficiencies where corneal vascularization has been reported, but there is no evidence that these pathological signs are in any way connected. It does, however, seem worth while to consider all changes which are common to animals showing vascularization of the cornea, as this sign appears in so many apparently unrelated nutritional deficiencies.

\section{SUMMARY}

I. The eyeball of the rat grows at a nor mal rate both in riboflavin and in tryptophan deficiency, although the growth of the rat itself and of the Harderian gland is slowed down. 
2. The histological picture of the Harderian gland is the same in both deficiencies.

3. There is a reduction in the ascorbic acid content of the Harderian gland in tryptophan deficiency.

This work owes a great deal to Miss M. Cross of the Laboratories of the Pharmaceutical Society of Great Britain. Many of the riboflavin-deficient rats were supplied by her, and I wish to thank her for her co-operation and help. I also wish to thank Glaxo Laboratories Ltd. for the gift of hydrolysed casein.

\section{REFERENCES}

Albanese, A. A., Holt, L. E., Kajdi, C. N. \& Frankston, J. E. (1943). J. biol. Chem. 148, 299.

Bellows, C. (1944). Cataract and Anomalies of the Lens. London: H. Kimpton.

Bessey, O. A. \& Wolbach, S. B. (1939). F. exp. Med. 69, 1.

Birch, T. W., Harris, L. J. \& Ray, S. N. (1933). Biochem. F. 27, 590.

Boyer, P. D., Phillips, P. H., Pounden, W. D., Jensen, C. W., Rupel, I. W. \& Nesbit, M. E. (1942). 7. Nutrit. 23, 525 .

Buschle, W. (1943). Arch. Ophthal., N.Y., 30, 735.

Collins, E. T. (1930). Trans. Ophthal. Soc. U.K. 50, 201.

Donaldson, H. H. (1924). The Rat. Philadelphia: The Wistar Institute.

Donski, J. (1932). v. Graefes Arch. Ophthal. r28, 294.

Figge, F. H. J. \& Salomon, K. (1942). F. Lab. clin. Med. 27, 1495.

Follis, R. H., Day, H. G. \& McCollum, E. V. (1941). F. Nutrit. 22, 223.

Follis, R. H., Orent-Keiles, E. \& McCollum, E. V. (1942). Arch. Path. 33, 504.

Jackson, C. M. (1913). Amer. Y. Anat. 15, 1.

Lee, O. S. \& Hart, W. A. (1944). Amer. F. Ophthal. 27, 488.

McMeekan, C. P. (1940a). J. agric. Sci. 30, 227.

McMeekan, C. P. (1940b). F. agric. Sci. 30, 387.

McMeekan, C. P. (r940c). F. agric. Sci. 30, 5 II.

Moore, T. (1940). Biochem. F. 34, 132 1.

Niven, C. F., Jr., Washburn, M. F. \& Sperling, G. A. (1946). Proc. Soc. exp. Biol., N.Y., 63, 106.

Pirie, A. \& Wood, C. (1946). Biochem.. 40, 557.

Ray, S. N., Gybrgy, P. \& Harris, L. J. (1935). Biochem. F. 29, 735.

Rosen, F., Huff, J. W. \& Perlzweig, W. A. (1946). Y. biol. Chem. 163, 343.

Salmon, W. O. \& Engel, R. W. (1940). Proc. Soc. exp. Biol., N.Y., 45, 621.

Stephenson, M. \& Clark, A. B. (1920). Biochem. F. $14,515$.

Sure, B., Theis, R. M. \& Harrison, R. T. (1939). F. biol. Chem. 129, 245.

Sydenstricker, V. P., Hall, W. K., Hock, C. W. \& Pund, E. R. (1946). Science, 103, 194.

Tansley, K. (1931). F. Physiol. 71, 45x.

Totter, J. R. \& Day, P. L. (1942). F. Nutrit. 24, 159. 